\title{
Reign list for the rulers of Gowa and Talloq
}

\author{
Rulers of Gowa to 1669
}

1 Tumanurung

2 Tumassalangga Baraya (son)

3 I Puang Lowe Lembang (son)

4 Tuniatabanri (son)

5 Karampang ri Gowa (son)

6 Tunatangkalopi (son)

7 Batara Gowa (son)

Tuniawang ri Parallakkenna

8 Tunijalloq ri Passukkiq (son)

9 Tumapaqrisiq Kallonna (son)

Karaeng Manngutungi,

Gallarrang Loaya

10 Tunipalangga (son)

Karaeng Lakiung

11 Tunibatta (brother)

Karaeng Dataq

12 Tunijalloq (son)

Karaeng Bontolangkasaq

13 Tunipasuluq (son)

Karaeng Bontolangkasaq

14 Tumamenang ri Gaukanna (brother) Sultan Alau'ddin

mid-14th century ${ }^{1}$

late 15th century to late 1510 or early 1511

ruled late 1510 or early 1511 to late 1546

ruled late 1546 to early 1565

lived 1511 to 1565

ruled 40 days in 1565

lived 1517 to 1565

ruled 1565 to 1590

lived 1545 to late 1590

ruled late 1590 to early 1593

(deposed)

lived 1575 to 5 July 1617

ruled 1593 to 15 June 1639

lived 1586 to 15 June 1639

1 This can only be an estimate, and assumes that reigns during this period averaged 20 years. The rulers of Gowa until the mid-eighteenth century for whom we have reliable dates had reigns averaging 14 years, and the rulers of Talloq had reigns averaging 21 years over the same period. Any earlier estimate for the tumanurung is unlikely. 
15 Tumamenang ri Papambatuna (son) ruled $1639^{2}$ to 5 Nov 1653 Sultan Malikussaid (Muhammad Said) lived 11 Dec $1607^{3}$ to 5 Nov 1653

Karaeng Ujung, Karaeng Lakiung

16 Tumamenang ri Ballaq Pangkana (son) ruled 1653 to 17 June 1669 (abdicated)

Sultan Hasanuddin lived 12 Jan 1631 to 12 June 1670

Karaeng Bontomangape

lived Dec $1733^{4}$ to 1753

Rulers of Talloq to 1673

1 Karaeng Lowe ri Sero (son of G6)

2 Tunilabu ri Suriwa (son)

3 Tunipasuruq, Karaeng ri Pasiq (son)

4 Tumenanga ri Makkoayang (son)

Karaeng Pattingalloang

5 Karaeng Bainea (daughter)

Karaeng Pattingalloang

6 Tunipasuluq (son)

7 Karaeng Matoaya (son of T4)

Sultan Abdullah, Tumamenang ri Agamana Karaeng Kanjilo, Karaeng Segeri

8 Karaeng Kanjilo (son)

Sultan Mudhaffar

Tumammaliang ri Timoroq

9 Karaeng Pattingalloang (brother)

Sultan Mahmud

Tumamenang ri Bontobiraeng

10 Tumamenang ri Lampana (son of T8) Sultan Harunarasyid

mid to late 15th century late 15 th century to 1500 s 1500 s to 1540 or 1543 ruled 1540 or 1543 to 1576 lived 1520 to 1576 late 1576 to 1590

late 1590 to early 1593 ruled 1593 to 1623 (advised son to 1636) lived 1573 to 1636

ruled 1623 to 18 May 1641 lived 1598 to 18 May 1641 ruled 1641 to 15 Sept 1654 lived Aug 1600 to 15 Sept 1654

ruled $1654^{5}$ to 16 June 1673 lived 3 Nov 1640 to 16 June 1673

2 There are two possible dates. The lontaraq bilang report both that he received the royal sunshade 3 July 1639 and was installed 19 December 1639. Usually ceremonially receiving the royal sunshade signified being installed as ruler.

3 This is the lontaraq bilang date. According to the Gowa chronicle he was born in 1606.

Exact date not given. 20 Rajab 1146 is the Islamic date.

According to a small collection of lontaraq bilang found in NBG 17, page 135-6, he was installed in early 1655, which is quite possible. 